\section{FEDERAÇÃO LATINO-AMERICANA DE PARASITólogos (FLAP)}

\author{
SEGUNDO CONGRESSO LATINO-AMERI- \\ CANO DE PARASITOLOGIA \\ 17 a 19 de setembro, 1970
}

\section{CIDADE DO MÉXICO}

A Federação Latino-americana de $\mathrm{Pa}$ rasitólogos teve seu primeiro Congresso em Santiago do Chile em 1967 scb a Presidência do Dr. Amador Neghme. Os novos diretores da Federação foram nomeados nesta oportunidade:

Presidente: Dr. Francisco Biagi, México Vice-Presidentes: Dr. David Botero, Colömbia

Dr. Hugo Lumbreras, Peru

Secretário-Tesoureiro: Dr. Jorge Tay, México.

Devido ao fato do Dr. Biagi estar no momento atual trabalhando na Organização Mundial de Saúde, Unidade de Enfermidades Parasitárias em Genebra, o Dr. David Botero, da Faculdade de Medicina, Universidade de Antioquia, Medellin, Colómbia, assumiu a presidência.

O próximo Congresso Latino-americano no México (17-19 de setembro de 1970) realizar-se-á logo depois do segundo Congresso Internacional de Parasitologia em Washington (6 a 12 de setembro de 1970), para facilitar a assistência a ambos.

Tôda a correspondência e os resumos dos trabalhos devem ser dirigidos a:

Dr. Jorge Tay

Universidade Nacional de Mexico Escuela de Medicina

Apartado: 20372

Mexico 20, MEXICO.

\section{CONFERENCIA INTERNACIONAL DE TÉTANO - São PaUlo, 1970}

Será realizada em São Paulo, no período de 17 a 22 de agôsto de 1970 , a III Conferência Internacional de Tétano, sob os auspicios da Organização Mundial de Saúde, Oficina Sanitária Pan-americana e Academia de Medicina de São Paulo. A III Conferência Internacional de Tétano terá como local de reuniōes as magníficas instalações dos Laboratórios Carlo Erba de São Paulo, que conta com perfeitas instalaçōes audio-visuais, serviço de gravaçāo e tradução simultânea, além de perfeito serviço de ar condicionado.

Deverão comparecer, além das delegaçōes oficiais da Organização Mundial de Saúde e Oficina Sanitária Pan-americana, já designadas, renomados cientistas de cêrca de 15 paises. As sessões serão distribuidas pelos seguintes temas: Microbiologia (Prof. Nishida, do Japão), Epidemiologia (Dr. Cvjetanovic, OMS), Imunilusia (Prof. Edsall, Estados Unidos), Profilaxia (Prof. Eckmann, Suissa), Terapêtica (Prof. Patel, India) e Estandardirações (Dra. Pitmann, Estados Unidos).

As sessōes constarão de conferências sôbre os respectivos assuntos, mesas redondas, temas livres e discussões abertas.

A Conferência tem como Presidente de honra o Senhor Governador do Estado e terá interessante programa de atividades sociais programadas pela secretaria de Turismo do Estado e Prefeitura de São Paulo.

O Presidente da II Conferência Internacional de Tétano é o Prof. Ricardo Veronesi - Caixa Postal, 8091, São Paulo. 


\title{
BEHAVIOUR OF A PERU STRAIN OF TRYPANOSOMA CRUZI IN RHESUS MONKEYS
}

\author{
P.D. Marsden; A. Voller; S. K. K. Seah; C. Hawkey and D. Green
}

\begin{abstract}
The course of infection with a Peru strain of $\mathrm{T}$. cruzi was studied in 3 rhesus monkeys. An unsuccessful attempt to vaccinate one monkey is described. Tho InM lonele rise during the course of infection in all 3 animals. A lummocytosis and mild andemia was noted in these acute infections. Orbital oedema occurred in all 3 animals following subcutaneous inoculation of the infection dose into the eyelid.
\end{abstract}

It was in the blood of the primate Callithrix penicillata ihat the first mammalian blood forms of Trypanosoma cru$z i$ were seen (Chagas, $:$ ). Since that time monkeys have been experimentally infected for a variety of reasons. Wood (18) infected a rhesus morkey with a Californian strain of T. cruzi. Both Romana (17) using South American strains and Davis (2) with a North American strain have produced orbital oedema in monkeys by conjunctival application of bug flagellates. Torres and Tavares (16), successfully infected Cebus monkeys with three strains of $T$. cruzi isolated frcm acute cases of Chagas' disease. They roint out that monkeys are particularly suitable for experiments of long duration since they survive the acute phase of the disease. Unexplained T. cruzi infections of Rhesus monkeys in laboratories have been noted (Fulton and Harrison, 5). Examining this problem Hoare feels that such infections in Indian monkeys could have been acquired in the various animal houses possibly by bed bug transmission. In wild monkeys in South America $T$. cruzi infections are widely prevalent (Dumn et al., 4; Marinkelle, 9).
One of our interesis in stuaying this infection in primates has been to evaluate vaccine therapy. Muniz et al. (13) were unsuccessful in demonstrating a protective action of a vaccine of merthiolate treated $T$. cruzi cultural forms in rhesus monkeys. We report here on two initial experiments using a Peru strain of Trypanosoma cruzi to infect rhesus monkeys.

\section{MATERIAL AND METHODS}

Infection was induced by inoculation of a known number of trypanosomes from mouse blood into the upper eyelid. This site was chosen because the anticipated subsequent oedema would give some indication of the progress of the infection. Parasitaemia was expressed as number of trypanosomes per 100 fields of a monolayer film of fresh blood, examined at a magnification of 500 times. Haematological observations done by standard techniques included haemoglobin, packed cell volume, red cell count, white cell count and differential, platelets, reticulocytes and blood sedimentation rate. The indirect fluorescent antibody test was the serological test employed in both experi-

Departament of Clinical Tropical Medicine, London School of Hygiene and Tropical Medicine and the Nuffield Institute of Comparative Medicine.

Accepted for publication on 6 January, 1970. 
ments and the complement fixation test was also done in the second experiment.

All 3 monkeys had their IgG and IgM levels estimated by the radial diffusion technique of Mancini et al. (8) using $\mathrm{Hy}-$ land Immunoplates.

These are expressed as percentage of the normal in the first experiment and as $\mathrm{mg} / 100 \mathrm{ml}$, in the second experiment. When the monkeys were killed tissues were fixed in $10 \%$ formol waline sectioned and stained with haematoxylin and eosin (By Dr. D. S. Ridley). In the first experiment conjunctival discharge, saliva and urine were examined for trypanosomes,

\section{RESULTS}

\section{Experiment 1.}

A male year old rhesus morkey (4.6 kilcs) was infected with the Peru strain of Trypanosoma cruzi originally isolated in Peru in 1963 (Nussenweig and Goble 14). The immediate previcus history of the isolate was that it had been brought from America in Rhodnius prolixus and had been passaged 5 times in CFI mice prior to this experiment. 4 million trypanosomes from mouse blood in one $\mathrm{mi}-$ llilitre of heparinised serum saline suspension were injected intc the right upper eyelid. Though initialiy there was no reaction, by the sixth day both lids of the right eye were red, oedematous and swollen. At this time trypanosomes were present in the conjunctival discharge. On the 17th day at the height of parasitaemia no trypanosomes could be deterted in the saliva or urine of the monkey either by direct examination, sentrifugation or culture.

Figure 1A shows the course of parasitaemia in relation to changes in the serum IgG, IgM and fluorescent antibody levels. The IgM level rose to a maximum on the 11th day and remained elevated. The IgG rose slightly at the end of the experiment. The fluorescent antibody level was slow to ise, but was still developing when the arimal was killed on the 34 th day.

Table I shows the haematological data gathered on this monkey.

The slow progressive fall in haemoglobin might conceivably be related to venepuncture although only $5 \mathrm{ml}$ of blood were withdrawn. The white cell count rose at the end of the exprriment and there was a very significant increase in the proportion of lymphocytes. There was no eosinophilia. When the animal was killed on the 34 th day the right eyelids were still red and sligthly swollen. A chronic inflammatory exsudate and leishmanial nests were present ir these eyelids but the left eyelids were rormal. Many nests of leishmania were found in the right parotid gland indicating the route of dissemination. Scanty leishmania were found in the auricles of the heart and the smooth muscle of the intestine. There was lymphocytic infiltration of all these organs and of the skeletal muscle. The liver showed fatty degeneration. No leishmania were round in brain biopsies. parotid gland, spleen, lung, testis or bladder. At the time of death the parasitaemia was subpatent and this animal would probably have gone on to develop a chronic infection.

\section{Experiment 2.}

Our experiment wais partly invalitated because monkey Number $25 \mathrm{which}$ we attempted to vaccinate developed tuberculosis of the lungs which was confirmed as post mortem. Dr Henry seneca of Columbia University, New York, kindly supplied us with some freeze dried extract of cultural $T$. cruzi of the Tulahuen strain prepared as describel in this paper (Seneca and Peer, 15). We gave the monkey 3 inoculation without adjuvant prior to infection at 33 days $(26 \mathrm{mg}$ intraperitoneally), at 30 days ( $40 \mathrm{mg}$ intraperitoneally) and at 13 days ( $40 \mathrm{mg}$ subcutaneously). No adjuvant was used and a slight rise in IgG level was noted during this schedule and tine complement fixation test became positive in low titre. Monkey Number 26 was given no vaccination and used as cuntrol saline only being infected.

Since both these male rhesus monkeys were half the weight of our previous monkey ( 2.3 silos) we gave them half the dose of trypanosomes ( 2 million) isolated from mouse clood after 77 previous passages in CFI mice by inoculation into the left upper eyelid. By 6 days 


\section{TABLE I}

\begin{tabular}{|c|c|c|c|c|c|}
\hline Days in relation to infection & -1 & +2 & +24 & +27 & +34 \\
\hline Haemoglobin $\%$. . . . . . . . . & 10.8 & 9.2 & 8.9 & 8.6 & 8.2 \\
\hline Packed cell volume.... & 37 & 34 & 30 & 29 & 30 \\
\hline Red cell count in millions & 4.65 & 3.63 & 3.66 & 3.4 & 3.92 \\
\hline White cell count $\times 10 ? \ldots \ldots$ & 11.54 & 12.36 & 10.36 & 13.48 & 14.28 \\
\hline$\tau_{\circ}$ neutrophils.$\ldots \ldots \ldots$ & 57 & 61.5 & 18.5 & 17.5 & 16.5 \\
\hline To lymphocytes .... & 34.5 & 29.0 & 74 & 72.5 & 78.5 \\
\hline Reticulocytes. . & 6 & 2.8 & 2.4 & 2.4 & 1.4 \\
\hline Platelets $\times 10$ & 233 & 357 & 276 & 231 & 229 \\
\hline
\end{tabular}

both monkeys had orbital oedema of the ieft eye. The non-vaccinated monkey is illustrated at 9 days (Figure 1) and 20 days (Figure 2). Trypanosomes were found in the conjunctival cischarge from both animals. As can be seen in the second photograph the lesions went on to ulcerate. The course of parasitaemia, haemoglobin, IgG and IgM levels and serological antibody titres are given in Table 2. The haemoglobin and PCV again fell although in the case of the tuberculous monkey (N.0 25) it is of little significance. While IgG levels remained static, again in both monkeys IgM levels rose. Both fluorescent antibody itres and complement fixing antibody titre showed a progressive rise with the passage of time. Our vaccination schedule did not appear to influence the cuurse of the disease. Both animals were killed on the 29 th day. The left eyelids of both monkeys showed leishmanial nests and a chroric inflammatory cell infiltrate of mainly lymphocytes. Similar lymphocytic infiltration was present in the auricular muscle and skeletal muscle but no leishmania were seen.

\section{DISCUSSION}

The Peru strain of Trypanosoma cruzi induces a non-fatal acute infection in rhesus monkeys since $?$ decline in parasitaemia is noted even in these short term experiments. The relatively mild tissue reactions and absence of leishmania other than at the site of inoculation is in keeping with this observation. A similar persistent multiplication at the site of inoculation has been noted in Beagle dogs (Marsden and Hagstrom, 10). Orbital oedema developed in all 3 monkeys with

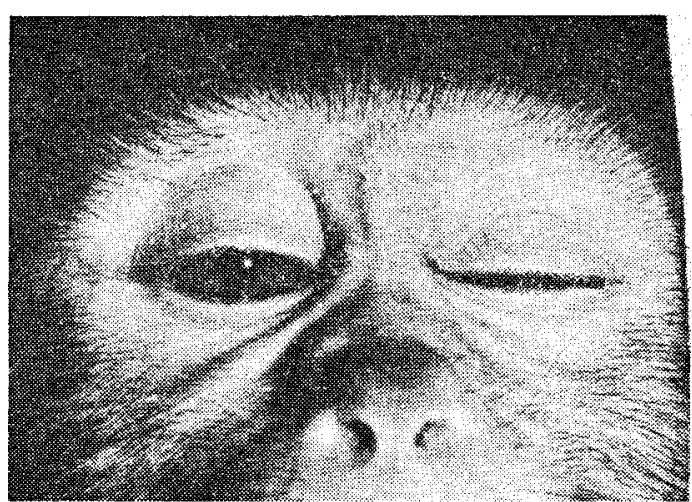

Fig. 1 -.. Orbital oedema in monkey 26 at 9 lays

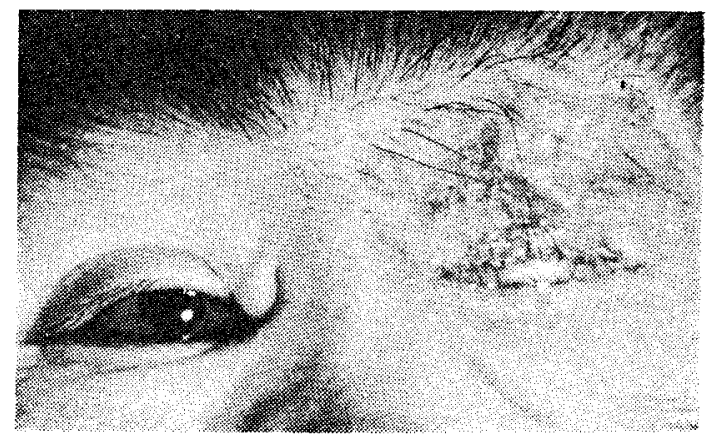

Fig. 2 Orbital oedema with ulceration in monkev 26 at 20 days.

this strain and was useful in assessing the progress of the infection. Such a reaction was rare in Beagle dogs inoculsted in a similar manner.

The marked lymphocytosis noted in the first experiment is a feature of human acute infections (Dias, 3). A fall in haemoglobin and PCV was noted in all 3 
Table 2

ASSEMBLED DATA OF EXPERIMENT 2

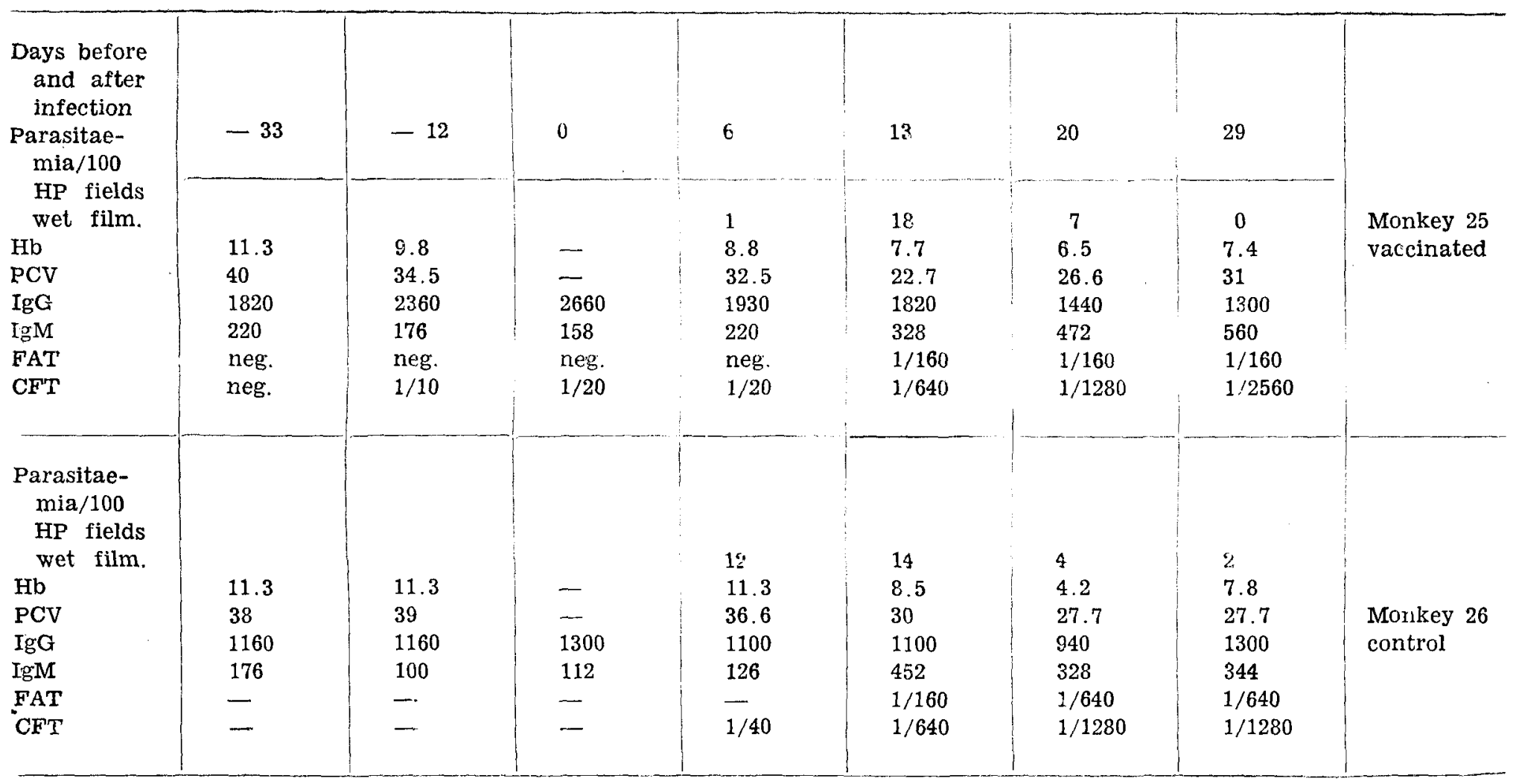


MALE RHESUS MONKEY I YEAR OLD WEIGHING 4 KILOS INFECTED WITH 4 MILLION MOUSE BLOOD TRYPANOSOMES IN SALINE IN RIGHT UPPER CANTHUS

$\therefore$ mber of

wasites/FAT of normal

100 fieids titre $\lg G \lg M$

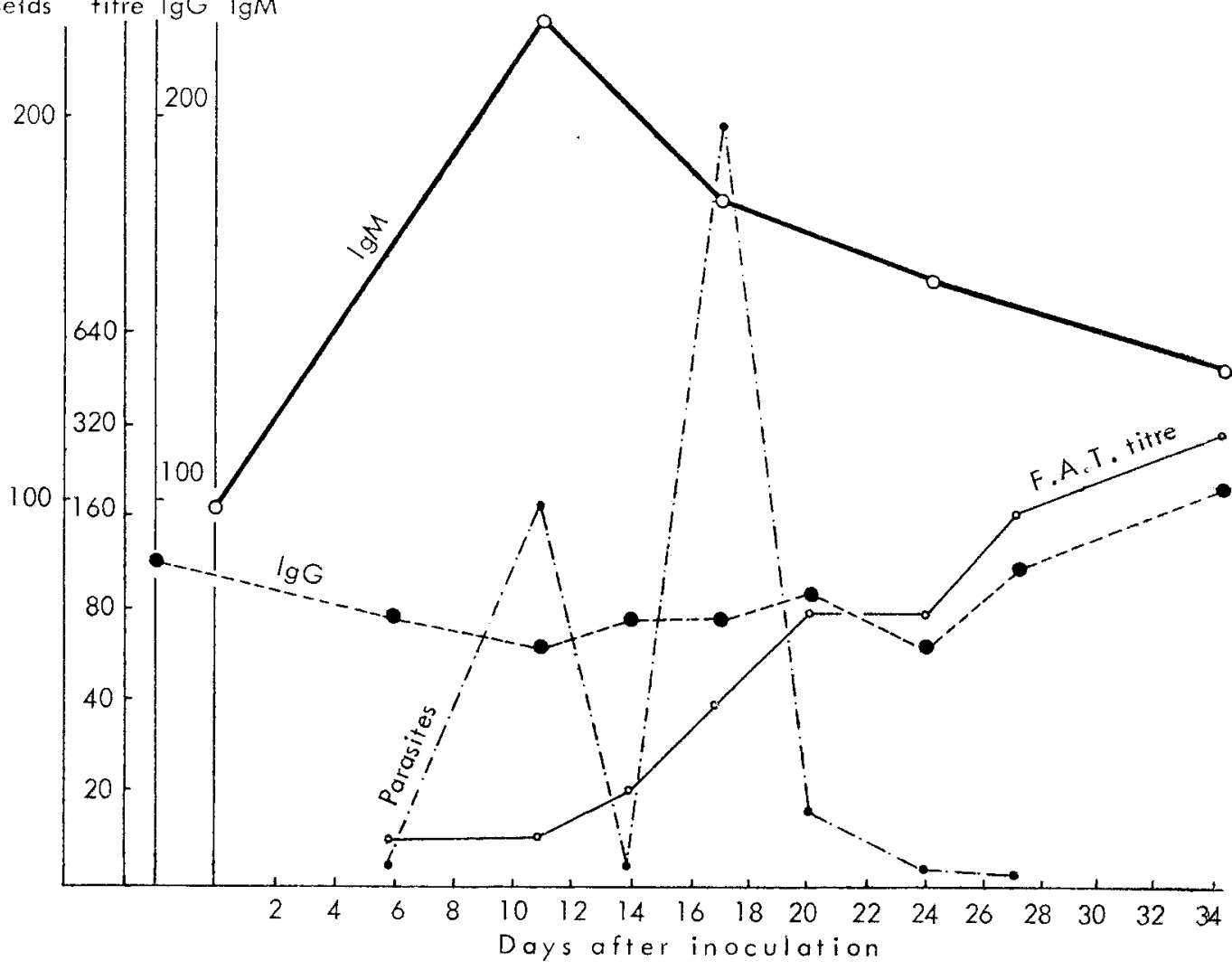

Experiment 1

Fig. 1A

monkeys during the course of the infection but this may be associated with venepuncture. If there is a true anaemia, from our data it appears to be normocytic normochromic anaemia. The reticulocyte count does not suggest active haemolysis.

Both the fluorescent antibody test and the complement fixation test showed rising titres with the course of the infection. It is noteworthy that a positive CFT was observed in the vaccinated animal before challenge with living organisms. Vaccination was not successful but the type of schedule can be modified and we were using an extract derived from a different strain. Currert experiments are in progress and designed to explore the use of adjuvants with a vaccine of freeze dried cultural forms of this Peru strain and make similar immunolozical observam tions on long term infections in rhesus monkeys. Perhaps the most interesting finding was the constint observation of a progressive rise in the IgM level while the IgG level showed little change. Similar elevation of the IgM levels has been noted in Trypanosoma brucei infections of 
monkeys (Mattern et al., 11), and is such a marked feature of human infections as to be of diagnostic value (Mattern et al,
12). It is important to ascertain whether a similar phenomenon occurs in human T. cruzi infections.

\section{REFERENCES}

1. CHaGas, C. - Mem. Inst. Oswaldo Cruz, 1:159, 1909.

2. DAVIS, D.J. - Fublic Hlth. Rep., 58:1006, 1943.

3. DTAS, F - Mem. Inst. Osw. Cruz, 4:34, 1912.

4. DUNN. F.L.; LAMBRECHT, F.L.; PLESSIS, R. - Am. J. Trop. Med. \& Hyg., 12:524, 1963.

5. FULTON, J.D.; IIARRISON, C.V. Trans. Roy. Soc. Trop. Med. \& Hyg., $39: 513,1946$.

6. GOBLE, F.C. - Abstracts 8th International Congress on Tropical Medicine and Malaria, Teheran, p. 367 , 1968.

7. HOARE, C.A. - J. f. Trop. Med. \& Hyg., 66:297, 1953.

8. MANCINI, G.; CARBONARA, A.O.: HEREMANS, J.E. - I I mmunochemistry, 2:235, 1365 .

9. MARINKELLE, C.J. - Trans. Roy. Soc. Trop. Med. \& Hyg., 60:109, 1966.
10. MARSDEN, P.D. \& HAGSTROM, J. W.C. - Trans. Rcy. Soc. Trop. Med. \& Hyg., 62:816, 1968.

11. MATTERN, P.; FROMENTIN, H.; PILO MORON, E. - Bull. Soc. Path. Exot., 56:301, 1963.

12. MATTERN, P.; MASSEYEFF, R.; MICHEL, R.; PERETTI, P. - Ann. Inst. Pasteur, 101:382, 196i.

13. MUNIZ J. NOBREGA, G; CUSTIA, M. - Mem. Inst. Osw. Crut, 44:529. 1946.

14. NUSSENWEIG, V.; GOBLT, F.C. Expt. Parasit., 18:224, 1966.

15. SENECA, H.; PEER, P. - Trans. Roy. Soc. Trop. Med. \& Hyg. - 60: $610,1966$.

16. TORRES, M.C. \& TAVARES, B.M. -Mem. Inst. Osw. Cruz, 56:85, 1958.

17. ROMANA, C. -- Bull. Soc. Path. Exot., 32:390, 1939.

18. WOOD, F.D. - Amer. J. Trop. Med.. 14:497, 1934 . 